\title{
Trichodina nobilis Chen, 1963 and Trichodina reticulata Hirschmann et Partsch, 1955 from ornamental freshwater fishes in Brazil
}

\author{
Martins, ML. *, Marchiori, N., Roumbedakis, K. and Lami, F. \\ AQUOS-Laboratory of Aquatic Organisms Health, Aquaculture Department, \\ Federal University of Santa Catarina - UFSC, Rod. Admar Gonzaga, 1346, CEP 88040-900, Florianópolis, SC, Brazil \\ *e-mail: mlaterca@cca.ufsc.br
}

Received March 24, 2011 - Accepted May 26, 2011 - Distributed May 31, 2012

(With 2 figures)

\begin{abstract}
In the present work Trichodina reticulata and T. nobilis (Ciliophora: Trichodinidae) are morphologically characterised from ornamental freshwater fish culture in the State of Santa Catarina, Brazil. The prevalence of infection and a list of comparative measurements are discussed. We examined "southern platyfish" Xiphophorus maculatus $(\mathrm{n}=35)$, “goldfish" Carassius auratus $(\mathrm{n}=31)$, "guppy" Poecilia reticulata $(\mathrm{n}=20)$, "sailfin molly" Poecilia latipinna $(\mathrm{n}=6)$, "beta" Betta splendens $(\mathrm{n}=2)$ and "spotted headstander" Chilodus punctatus $(\mathrm{n}=1)$. After being anesthetised in a benzocaine solution, fishes were examined for parasitological evaluation. A total of $51.57 \%$ fishes were parasitised by Trichodina spp. Carassius auratus was the most parasitised species, followed by X. maculatus and P. reticulata. Beta splendens, C. punctatus and P. latipinna were not parasitised by any trichodinid species. Two species of Trichodina were collected from the skin of fish: T. nobilis was found in C. auratus, P. reticulata and X. maculatus and T. reticulata was only observed in $C$. auratus. The importance of adequate handling in ornamental fish culture are also discussed.
\end{abstract}

Keywords: ornamental fish, parasites, Trichodina nobilis, Trichodina reticulate.

\section{Trichodina nobilis Chen, 1963 e Trichodina reticulata Hirschmann et Partsch, 1955 de peixes ornamentais de água doce no Brasil}

\begin{abstract}
Resumo
No presente trabalho Trichodina reticulata e T. nobilis (Ciliophora: Trichodinidae) de peixes ornamentais de água doce cultivados no estado de Santa Catarina, Brasil são caracterizadas morfologicamente. A prevalência de infecção e uma lista comparative de medidas são discutidas. Foram examinados "platis" Xiphophorus maculatus (n= 35), "kinguios", Carassius auratus $(\mathrm{n}=31)$, "guppys" Poecilia reticulata $(\mathrm{n}=20)$, "molinésias" Poecilia latipinna $(\mathrm{n}=6)$, "betas" Betta splendens $(n=2)$ e "espada" Chilodus punctatus $(n=1)$. Após a anestesia com solução de benzocaína, os peixes foram submetidos à avaliação parasitológca. Um total de 51,57\% peixes estavam parasitados por Trichodina spp. Carassius auratus foi a espécie mais parasitada, seguida por X. maculatus e P. reticulata. Beta splendens, C. punctatus e P. latipinna não estavam parasitados por tricodinídeos. Duas species de Trichodina foram coletadas da superfície corporal dos peixes: T. nobilis foi encontrada em C. auratus, P. reticulata e X. maculatus e T. reticulata foi observada apenas em $C$. auratus. A importância do manejo adequado em cultivos de peixes ornamentais também foi discutida.
\end{abstract}

Palavras-chave: peixes ornamentais, parasitos, Trichodina nobilis, Trichodina reticulata. 


\section{Introduction}

Ornamental fish culture in Brazil has shown a rapid development in the last years (Piazza et al., 2006). As a function of the intensive culture, many parasitic and infectious diseases have emerged thereby causing serious damage to fish production (Kim et al., 2002). Under inadequate handling such as high content of organic matter, depletion of dissolved oxygen, water temperature alterations, nutritional deficiency and the lack of quarantine of introduced fish in fish farms, trichodinids find adequate substrate to reproduce causing damage to fish and consequently economic losses (Moraes and Martins, 2004).

Trichodinid ciliates are one of the most common ectoparasites in both wild and cultivated fish (Basson and Van As, 1994, Martins and Ghiraldelli, 2008). However, in Brazil, studies concerning their identification have received little attention and require further investigation. Up to now, Trichodina spp. from ornamental fish were reported in Paracheirodon axelrodi (Ferraz, 1999), Xiphophorus helleri and Xiphophorus maculatus (Garcia et al., 2009). Piazza et al. (2006) registered Trichodina acuta Lom, 1961 in X. helleri, $X$. maculatus, Poecilia sphenops, Beta splendens and Carassius auratus.

This study characterises morphologically Trichodina reticulata Hirschmann et Partsch, 1955 and Trichodina nobilis Chen, 1963 collected from ornamental freshwater fishes in the state of Santa Catarina, Brazil. Prevalence and a list of comparative measurements are also reported.

\section{Material and Methods}

Ninety five ornamental freshwater fishes were caught from a fish store at Florianópolis, Santa Catarina state, Brazil, between August and October 2009. Fish species examined in this study were: "southern platyfish" Xiphophorus maculatus ( $\mathrm{n}=35)$, "goldfish" Carassius auratus $(\mathrm{n}=31)$, "guppy" Poecilia reticulata $(\mathrm{n}=20)$, "sailfin molly" Poecilia latipinna $(\mathrm{n}=6)$, "beta" Betta splendens $(\mathrm{n}=2)$ and "spotted headstander" Chilodus punctatus $(\mathrm{n}=1)$. Before necropsies, fishes were maintained in a $30 \mathrm{~L}$ aquarium for approximately five days. Fishes were sacrificed (ethics committee-CEUA

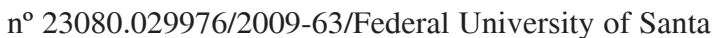
Catarina) and analysed under a stereomicroscope for the presence of trichodinids.

Wet smears of the skin and gills were air-dried at room temperature and impregnated with silver nitrate by Klein's method for posterior examination of the adhesive disc structures and denticles under an optic microscope, as suggested by Lom (1958). Specimens are deposited in the National Institute of Amazonian Research (INPA), Manaus, AM, Brazil. All measurements (in micrometers) were made in a camera lucida. Arithmetic means \pm standard deviation are followed, in parentheses, by the minimum, maximum values and the number of measured structures. Denticles description follows the recommendation of Van As and Basson (1989).

\section{Results}

A total of $51.57 \%$ of examined fish were parasitised by Trichodina spp. Carassius auratus was the most parasitised species, followed by $X$. maculatus and $P$. reticulata (Table 1). Beta splendens, C. punctatus and P. latipinna were not parasitised by any trichodinid species (Table 1). Two species of Trichodina were recovered from the skin of ornamental freshwater fishes: Trichodina nobilis was found in $C$. auratus, $P$. reticulata and $X$. maculatus and T. reticulata was only observed in C. auratus.

Trichodina reticulata Hirschmann and Partsch, 1955 (Figures 1a and 2a).

Description based on 50 specimens: Characterised as medium to large trichodinid (Table 2). Denticle blade fills the space between y and y-1 axes, very angular on outside margin with an angular apex not clearly demarcated. Distal blade margin rounded, leaning considerably down towards tangent point. Posterior margin of the blade shows a semilunar curve. Central part with a narrow retreat on its anterior margin (only seen in some specimens) and rounded posterior tip. Central part reaches halfway of the space between y and $y+1$ axes (Figure $2 \mathrm{a}$ ). Ray thick throughout its length, with a round tip slightly trespassing the axis y. Ray apophysis not clearly visible. Prominent

Table 1. Ornamental fish species from Florianópolis, Santa Catarina, Brazil, their common names, total length and prevalence of Trichodina spp.

\begin{tabular}{lccccc}
\hline \multicolumn{1}{c}{ Species } & Common name & Total length & PF/EF & P $(\%)^{\mathbf{a}}$ & $\left.\mathbf{P}^{\mathbf{c}} \mathbf{\%}\right)^{\mathbf{b}}$ \\
\hline Beta splendens & Betta & 4.6 & $0 / 2$ & 0 & 0 \\
Chilodus punctatus & $\begin{array}{c}\text { Spotted } \\
\text { headstander }\end{array}$ & 4.5 & $0 / 1$ & 0 & 0 \\
Poecilia reticulata & Guppy & $3.06 \pm 0.68$ & $3 / 20$ & 15 & 3.15 \\
Carassius auratus & Goldfish & $6.39 \pm 1.87$ & $23 / 31$ & 74.19 & 24.21 \\
Poecilia latipinna & Sailfin molly & $3.93 \pm 0.66$ & $0 / 6$ & 0 & 0 \\
Xiphophorus maculatus & Southern platyfish & $3.73 \pm 0.64$ & $23 / 35$ & 65.71 & 24.21 \\
Total & - & - & $49 / 95$ & - & 51.57 \\
\hline PF:paratit
\end{tabular}

PF: parasitised fish; EF: examined fish; $\mathrm{P}^{\mathrm{a}}$ : prevalence in relation to total number of each examined fish species; $\mathrm{P}^{\mathrm{b}}$ : prevalence in relation to total number of examined fish. 


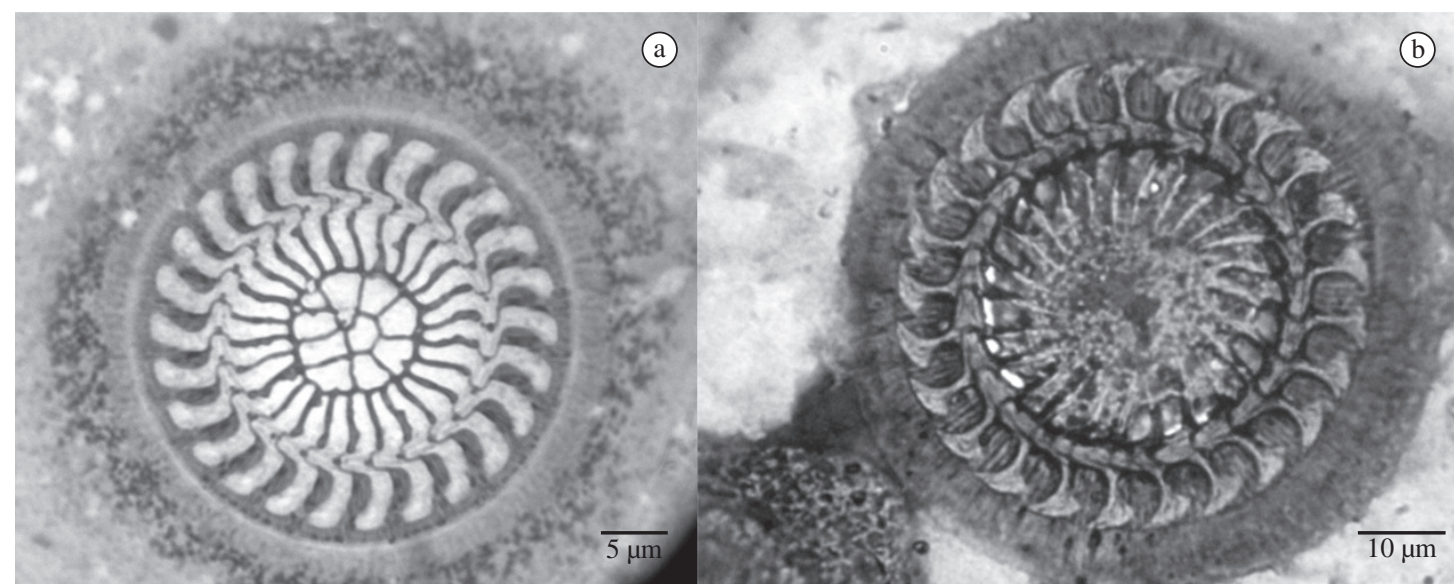

Figure 1. Photomicrographs of (a) Trichodina reticulata, scale: $5 \mu \mathrm{m}$ and (b) Trichodina nobilis, scale: $10 \mu \mathrm{m}$ from ornamental freshwater fishes cultured in the state of Santa Catarina, Brazil.

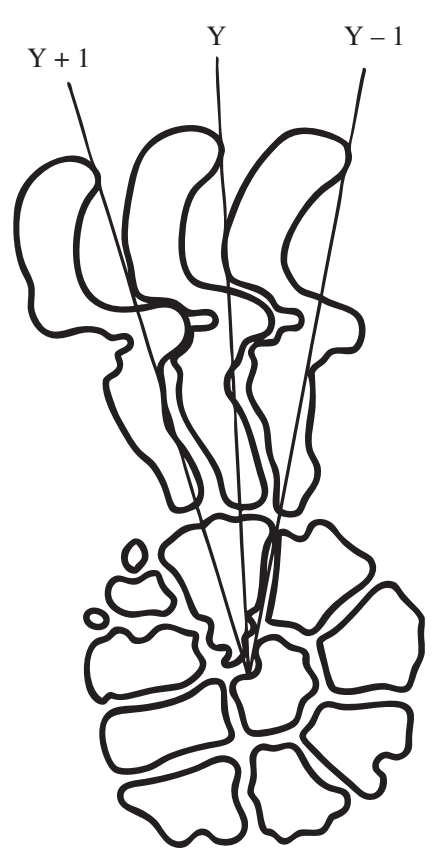

(a)

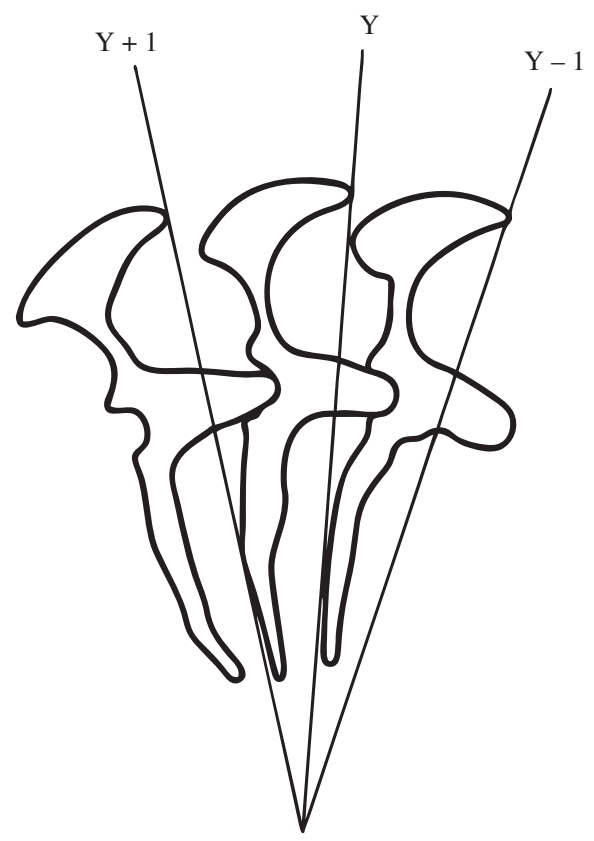

Figure 2. Schematic drawing of the denticles of (a) Trichodina reticulata and (b) Trichodina nobilis.

radial pins. Centre of adhesive disc with circular cell-like structures varying in size and number (6 to 16).

\section{Taxonomix summary}

Host: Carassius auratus

New Locality: Florianópolis, Santa Catarina State, Brazil

Site of infection: skin

Synonyms: Trichodina domerguei f. megamicronucleus Dogiel, 1940; Trichodina megamicronucleata Dogiel, 1950 (see Wellborn, 1967).

\subsection{Remarks}

According to Dove and O’Donoghue (2005), T. reticulata is a highly distinctive species well-known as a pathogen of Carassius spp. and other cyprinids kept for aquaculture and aquaria. It lives in the mucus of the body surface (rarely on the gills) (Lom, 1960) and presents a very distinct feature which is the presence of some circular cell-like structures in the centre of the adhesive disc. The species has a wide distribution, having been reported widely from the Czech Republic (Lom, 1960), China (Chen, 1963), Japan (Ahmed, 1976, 1977), Philippines (Albaladejo and Arthur, 1989), North America (Hirschmann and Partch, 1955; Wellborn, 
1967), Israel (Basson et al., 1983), South Africa (Basson and Van As, 1993), India (Mishra and Das, 1993), Germany (Dobberstein and Palm, 2000), Australia (Dove and O’Donoghue, 2005) and Iran (Moghaddam et al., 2010).

With regard to host specificity, Wellborn (1967) registered a strong case of $T$. reticulata in the cyprinid Abrama abrama. In the same way, in this study the species was only found in C. auratus, which suggests that it may be host-specific for certain cyprinid fish.

The measurements from the present studied population agree with previous descriptions, showing some variation with the populations studied by Wellborn (1967) and Lom (1960), both presenting greater body length than the current one (Table 2). This is the first register of $T$. reticulata in Brazil and South America.

Trichodina nobilis Chen, 1963 (Figures 1b and 2b).

Description based on 32 specimens: characterised as a large trichodinid (Table 3), disc-shaped. Adoral spiral of about $440^{\circ}$. Anterior blade margin slightly curved. Distal margin of the blade rounded filling almost all space between the axes $y$ and $y+1$, leaning down towards the tangent point and also towards the blade apex. Blade suffers a remarkable narrowing through its middle section, slightly broadening at blade connection. Posterior margin of the blade shows a deep semi lunar curve. Detachable blade apophysis, with acuminate point. Central part with rounded tip, fitting tightly into preceding denticle and do not pass the half of the space between the axes $y$ and $y+1$. Long ray, straight to slightly curved in posterior direction situated between the axes y and $y+1$. Ray apophysis discrete and small. Tip of ray sharp. Micro and macronucleus not visualised.

\section{Taxonomix summary}

Host: Carassius auratus

New hosts: Poecilia reticulata, Xiphophorus maculatus

New Locality: Florianópolis, Santa Catarina State, Brazil

Site of infection: skin

Table 2. Comparative measurements of Trichodina reticulata. The averages \pm standard deviation are followed by minimum and maximum values in parenthesis.

\begin{tabular}{|c|c|c|c|c|}
\hline & T. reticulata & T. reticulata 2 & T. reticulata3 & T. reticulata4 \\
\hline Characters & Present study ${ }^{1}$ & $\begin{array}{l}\text { Hirschmann and } \\
\text { Partsch, } 1955 \text { in } \\
\text { Albaladejo and } \\
\text { Arthur (1989) }\end{array}$ & $\begin{array}{l}\text { Hirschmann and } \\
\text { Partsch, } 1955 \text { in } \\
\text { Wellborn (1967) }\end{array}$ & $\begin{array}{l}\text { Hirschmann and } \\
\text { Partsch, } 1955 \text { in } \\
\text { Basson, Van As and } \\
\text { Paperna (1983) }\end{array}$ \\
\hline Body $^{\mathrm{D}}$ & $55.0 \pm 7.6(44.2-68.6)$ & $60.8(57.0-8.5)$ & $80(71-95)$ & $54.4(45.2-58.6)$ \\
\hline Adhesive disc ${ }^{\mathrm{D}}$ & $45.5 \pm 5.6(36.3-55.2)$ & $46.0(46.0-57.0)$ & $59(48-66)$ & $45.0(35.8-49.5)$ \\
\hline Denticulare ring ${ }^{\mathrm{D}}$ & $28.7 \pm 5.2(19.7-41.0)$ & $34.2(31.0-37.0)$ & $38(31-41)$ & $29.3(22.0-33.4)$ \\
\hline Denticle number & $26.3 \pm 1.1(25-28)$ & $23.7(22-26)$ & $28(23-33)$ & $28.7(22-29)$ \\
\hline Pins per denticle & $9.7 \pm 0.7(9-10)$ & $10-12$ & 10 & $9.7(8.0-9.0)$ \\
\hline Denticle Length ${ }^{\mathrm{L}}$ & $5.1 \pm 0.9(3.9-7.8)$ & $7.7(7.5-8.5)$ & $10(8-12)$ & $6.2(5.0-7.2)$ \\
\hline Blade $^{\mathrm{L}}$ & $5.5 \pm 0.8(2.3-7.8)$ & $7.0(6.0-7.5)$ & $8(6.5-9)$ & $4.8(3.8-5.3)$ \\
\hline Central part ${ }^{w}$ & $2.2 \pm 0.3(1.5-3.1)$ & $2.0(1.5-2.0)$ & $2.9(2.0-3.0)$ & $2.3(1.3-3.4)$ \\
\hline Ray $^{\mathrm{L}}$ & $5.2 \pm 0.8(3.9-7.8)$ & $5.0(5.0-7.5)$ & $7-8$ & $6.0(4.3-7.0)$ \\
\hline Span & $13.3 \pm 1.3(11.8-16.5)$ & $15.2(14.5-16.5)$ & - & - \\
\hline & T. reticulata 1 & T. reticulata2 & T. reticulata3 & T. reticulata3 \\
\hline Characters & $\begin{array}{l}\text { Hirschmann and } \\
\text { Partsch, } 1955 \text { in } \\
\text { Dobberstein and } \\
\text { Palm }(2000)\end{array}$ & $\begin{array}{l}\text { Hirschmann and } \\
\text { Partsch, } 1955 \\
\text { in Dove and } \\
\text { O'Donoghue(2005) }\end{array}$ & $\begin{array}{c}\text { Hirschmann and } \\
\text { Partsch, } 1955 \text { in } \\
\text { Basson and Van As } \\
\text { (1993) }\end{array}$ & $\begin{array}{l}\text { Hirschmann and } \\
\text { Partsch, } 1955 \text { in } \\
\text { Lom, } 1960\end{array}$ \\
\hline Body $^{\mathrm{D}}$ & $61(57-69)$ & - & $47.9(40.0-55.0)$ & $74(55-88)$ \\
\hline Adhesive disc ${ }^{\mathrm{D}}$ & $46(46-57)$ & $48.6(40.9-54.2)$ & $39.3(31.0-46.0)$ & $52(44-57)$ \\
\hline Denticulare ring ${ }^{\mathrm{D}}$ & $34(31-37)$ & - & $24.7(20.5-29.0)$ & $32(25-36)$ \\
\hline Denticle number & $24(22-26)$ & $24(23-25)$ & $24(22-27)$ & $24,25(21-34)$ \\
\hline Pins per Denticle & $10-12$ & $10(9-11)$ & $9(8-10)$ & 10 \\
\hline Denticle Length $^{\mathrm{L}}$ & - & - & $5.2(4.0-6.0)$ & - \\
\hline Blade $^{\mathrm{L}}$ & - & $5.6(4.8-6.7)$ & $5.2(4.5-6.5)$ & - \\
\hline Central Part ${ }^{\mathrm{w}}$ & - & $2.5(2.2-2.9)$ & $1.8(1.0-2.0)$ & - \\
\hline Ray $^{\mathrm{L}}$ & - & $5.2(4.2-5.8)$ & $4.9(3.5-6.0)$ & - \\
\hline Span & - & $13.8(11.8-14.9)$ & $12.1(10.0-14.5)$ & - \\
\hline
\end{tabular}

Hosts. ${ }^{1,2,3}$ Carassius auratus, ${ }^{4}$ C. auratus, Ctenopharyngodon idella and Hypophthalmichthys molitrix. ${ }^{\mathrm{D}}$ Diameter, ${ }^{\mathrm{L}}$ length, ${ }^{\mathrm{w}}$ width. Hosts. ${ }^{1}$ Non provided, ${ }^{2}$ C. auratus and C. carpio, ${ }^{3}$ C. auratus. ${ }^{\mathrm{D}}$ Diameter, ${ }^{\mathrm{L}}$ length, ${ }^{\mathrm{w}}$ width. 
Table 3. Comparative measurements of Trichodina nobilis. The averages \pm standard deviation are followed by minimum and maximum values in parenthesis.

\begin{tabular}{|c|c|c|c|c|}
\hline & T. nobilis1 & T. nobilis 2 & T. nobilis3 & T. nobilis4 \\
\hline Characters & Present study & $\begin{array}{c}\text { Chen, } 1963 \text { in } \\
\text { Basson and Van As } \\
(1994)\end{array}$ & $\begin{array}{c}\text { Chen, } 1963 \text { in } \\
\text { Dobberstein and } \\
\text { Palm (2000) } \\
\end{array}$ & $\begin{array}{c}\text { Chen, } 1963 \text { in } \\
\text { Albaladejo and } \\
\text { Arthur (1989) }\end{array}$ \\
\hline BodyD & $77.7 \pm 5.7(67.8-86.8 ; 10)$ & $69.2(63-76)$ & $79(70-90)$ & $78.9(70.0-90.0)$ \\
\hline Adhesive disc ${ }^{\mathrm{D}}$ & $65.1 \pm 7.9(50.0-76.5 ; 10)$ & $57.3(50.5-63)$ & $65(58-77)$ & $65.5(58.0-77.0)$ \\
\hline Denticulare ring ${ }^{\mathrm{D}}$ & $44.8 \pm 5.9(37.1-56.8 ; 10)$ & $35.9(30.0-40.0)$ & $44(39-53)$ & $44.3(38.5-52.5)$ \\
\hline Denticle number & $26.5 \pm 0.8(25-28 ; 10)$ & $22(21-27)$ & $25(23-28)$ & $24.8(23.0-28.0)$ \\
\hline Pins per Denticle & $12 \pm 0.7(11-13 ; 8)$ & $12(11-13)$ & $12-14$ & $12-14$ \\
\hline Denticle Length ${ }^{\mathrm{L}}$ & $9.2 \pm 1.2(7.8-13.4 ; 30)$ & $9.6(8-11)$ & - & $11.0(10.5-12.5)$ \\
\hline Blade $^{\mathrm{L}}$ & $7.7 \pm 0.5(6.3-8.6 ; 30)$ & $7.5(6.5-9.0)$ & - & $9.1(7.5-10.5)$ \\
\hline Central Part ${ }^{\mathrm{w}}$ & $2.66 \pm 0.5(2.3-3.9 ; 30)$ & $3.0(2.5-3.5)$ & - & $2.4(2.0-3.0)$ \\
\hline Ray $^{\mathrm{L}}$ & $10.3 \pm 1.3(7.8-12.6 ; 31)$ & $9.9(9.0-11.5)$ & - & $10.7(8.0-13.0)$ \\
\hline Span & $21.9 \pm 2.2(15.0-27.3 ; 31)$ & $20.4(19.0-24.0)$ & - & $22.2(19-25)$ \\
\hline
\end{tabular}

Hosts. ${ }^{1}$ C. auratus, Poecilia reticulata (new host), Xiphophorus maculatus (new host), ${ }^{2}$ C. auratus, Capoeta semifasciolata, C. idella, H. molitrix, Poecilia velifera, P. reticulata and tilapia, ${ }^{3}$ Non provided, ${ }^{4}$ C. idella, Aristichthys nobilis and C. carpio. DDiameter, Llength, ${ }^{\text {w } w i d t h . ~}$

\subsection{Remarks}

Trichodina nobilis was first described by Chen (1963) parasitising cyprinids. Subsequently, it has been reported from several localities including China (Chen, 1963), Amur river (Stein, 1968; Yukhimenko, 1972), Ural (Kashkovsky, 1974), Bulgaria (Golemansky and Grupcheva, 1975), Philippines (Albaladejo and Arthur, 1989), Taiwan (Basson and Van As, 1994), Republic of Serbia (Nikolic et al., 2003) and Iraq (Al-Marjan and Abdullah, 2007). Hertel et al. (2004) reported a possible occurrence of $T$. nobilis parasitising Biomphalaria glabrata from Brazil through molecular techniques but since the same was not observed directly, the authors named it as Trichodina sp. This study can therefore be considered the first register of T. nobilis in Brazil and South America.

As for the site of infection, the species is reported on both skin and gills (rarely). Nikolic et al. (2003) studied the microhabitat preference of T. nobilis on its host and concluded its preference for fish skin. In this study, the parasite was only found in the skin of the hosts.

The population of T. nobilis found in this study agrees in shape and size with previous descriptions (Albaladejo and Arthur, 1989; Basson and Van As, 1994; Dobberstein and Palm, 2000) for the species (Table 3), leaving no doubt that it is T. nobilis. Poecilia reticulata and X. maculatus are considered new hosts for the species. The indentation in the anterior side of the blade reported by Basson and Van As (1994) was also observed in our specimens.

Data from Piazza et al. (2006) for T. acuta from ornamental freshwater fish collected at the same locality of the present study showed total prevalence of $4.7 \%$ including some host species also analysed in the present study such as $X$. maculatus and $C$. auratus. The present study, however, showed higher prevalence values than the former one, being $C$. auratus the most parasitised host species.
According to Piazza et al. (2006), diseases have caused economical losses of about 10 to $20 \%$ in cultured fish. Since this ciliated protozoan is able to cause considerable damage in cultured fish (Ghiraldelli et al., 2006), sanitary handling should be severaly applied in order to prevent massive mortalities under culture conditions.

Acknowledgements - The authors thank the National Council of Scientific and Technological Development (CNPq) for financial support to M.L. Martins and Benjamin Teixeira (Federal Institute of Santa Catarina, Araquari, SC, Brazil) for kindly giving us fish utilised in this study. The manuscript was critically reviewed by Anita Rademaker Valença and Eduardo Luiz Tavares Gonçalves.

\section{References}

AHMED, ATA., 1976. Trichodiniasis of goldfish and other carps. Bangladesh Journal of Zoology, vol. 4, p. 12-20.

-, 1977. Morphology and life history of Trichodina reticulata from goldfish and other carps. Fish Pathology, vol. 12, no. 1, p. 21-31. http://dx.doi.org/10.3147/jsfp.12.21

ALBALADEJO, JD. and ARTHUR, JR., 1989. Some trichodinids (Protozoa: Ciliophora: Peritrichida) from freshwater fishes imported into the Philippines. Asian Fisheries Science, vol. 3, p. 1-25.

AL-MARJAN, KSN. and ABDULLAH, SMA., 2007. Trichodinids ectoparasite (Ciliophora: Peritrichida: Trichodinidae) from common carp Cyprinus carpio in Iraq. Journal of Dohuk University, vol. 10 , no. 1 , p. 50-55.

BASSON, L. and VAN AS, JG., 1993. First record of the european Trichodinids (Ciliophora: Peritrichida), Trichodina acuta Lom, 1961 and T. reticulata Hirschmann et Partsch, 1955 in South Africa. Acta Protozoologica, vol. 32, p. 101-105.

-, 1994. Trichodinid ectoparasites (Ciliophora: Peritrichida) of wild and cultured freshwater fishes in Taiwan, with notes on their origin. Systematic Parasitology, vol. 28, p. 197-222. http:// dx.doi.org/10.1007/BF00009518 
BASSON, L., VAN AS, JG. and PAPERNA, I., 1983. Trichodinid ectoparasites of cichlid and cyprinid fishes in South Africa and Israel. Systematic Parasitology, vol. 5, p. 245-257. http://dx.doi. org/10.1007/BF00009159

CHEN, CL., 1963. Studies on ectoparasitic trichodinids from freshwater fish, tadpole and crustacean in China. Acta Hydrobiologica Sinica, vol. 3, p. 99-111.

DOBBERSTEIN, RC. and PALM, HW., 2000. Trichodinid ciliates (Peritrichia: Trichodinidae) from the Bay of Kiel, with description of Trichodina claviformis sp. n. Folia Parasitologica, vol. 47, p. 81-90.

DOVE, ADM. and DONOGHUE, PJO., 2005. Trichodinids (Ciliophora: Trichodinidae) from Native and Exotic Australian Freshwater Fishes. Acta Protozoologica, vol. 44, p. 51-60.

FERRAZ, E., 1999. Management and diseases of the ornamental fish exported from the Rio Negro basin. In VAL, AL. and VAL, VMFA. Biology of Tropical Fishes. Manaus: INPA. p. 99-111

GARCIA, F., FUJIMOTO, RY., MARTINS, ML. and MORAES, FR., 2009. Protozoan parasites of Xiphophorus spp. (Poeciliidae) and their relation with water characteristics. Arquivo Brasileiro de Medicina Veterinaria e Zootecnia, vol. 61, no. 1, p. 156-162. http://dx.doi.org/10.1590/S0102-09352009000100022

GHIRALDELLI, L., MARTINS, ML., ADAMANTE, WB. and YAMASHITA, MM., 2006. First record of Trichodina compacta Van As and Basson, 1989 (Protozoa: Ciliophora) from cultured Nile Tilapia in the state of Santa Catarina, Brazil. International Journal of Zoological Research, vol. 2, no. 4, p. 369-375. http:// dx.doi.org/10.3923/ijzr.2006.369.375

GOLEMANSKY, V. and GRUPCHEVA, G., 1975. Studies on the unicellular parasites of herbivorous fishes-of-the-year in Bulgaria. Acta Zoologica Bulgarica, vol. 2, p. 3-14.

HERTEL, LA., BARBOSA, CS., SANTOS, RALL. and LOKER, ES., 2004. Molecular identification of symbionts from the pulmonate snail Biomphalaria glabrata in Brazil. Journal of Parasitology, vol. 90, n. 4, p. 759-763. PMid:15357065. http:// dx.doi.org/10.1645/GE-223R

HIRSCHMANN, H. and PARTSCH, K., 1955. Ein einzelliger fischparasit von uberraschender Schoneit. Umshau, vol. 17, p. $525-527$.

KASHKOVSKY, VV., 1974. Urceolariids (Ciliata, Peritricha) from fishes of Ural. Parazitologiya, vol. 14, p. 504-510.

KIM, JH., HAYWARD, CJ. and HEO, GJ., 2002. Nematode worm infections (Camallanus cotti, Camallanidae) in guppies (Poecilia reticulata) imported to Korea. Aquaculture, vol. 205, p. 231-235. http://dx.doi.org/10.1016/S0044-8486(01)00691-3

LOM, J., 1958. Contribution to the systematics and morphology of endoparasitic trichodinids from amphibians, with a proposal of uniform specific characteristics. Journal of Protozoology, vol. 5, p. 251-263.

-, 1960. Trichodina reticulata Hirschmann and Partsch, 1955 from curcian carp, and T. domerguei f. latispina Dogiel, 1940 from Diaptomus. Vestnik Ceskoslovenske Zoologicke Spolecnosti, vol. 24 , p. $246-257$.

MARTINS, ML. and GHIRALDELLI, L., 2008. Trichodina magna Van As and Basson, 1989 (Ciliophora: Peritrichia) from cultured Nile tilapia in the state of Santa Catarina, Brazil. Brazilian Journal of Biology, vol. 68, no. 1, p. 169-72. http://dx.doi.org/10.1590/ S1519-69842008000100024

MISHRA, RK. and DAS, MK., 1993. Urceolariid ciliate, Trichodina reticulata infesting gills of Catla catla in India. Journal of Inland Fisheries Society, vol. 25, p. 54-56.

MOGHADDAM, BS., MOKHAYER, B., MASOUMIAN, M., SHENAVAR MASOULEH, A., JALILPOUR, J., MASOUMZADEH, M. and ALIZADEH, M., 2010. Parasitic infection among larvae and fingerlings of the Persian sturgeon (Acipenser persicus) in Vniro tanks and earthen ponds. Iranian Journal of Fisheries Science, vol. 9, no. 3, p. 342-351.

MORAES, FR. and MARTINS, ML., 2004. Condições predisponentes e principais enfermidades de teleósteos em piscicultura intensiva. In CYRINO, JEP., URBINATI, EC., FRACALOSSI, DM. and CASTAGNOLLI, N. Tópicos especiais em piscicultura de água doce tropical intensiva. São Paulo: TecArt. p. 343-383.

NIKOLIC, V., SIMONOVIC, P. and POLEKSIC, V., 2003. Preference of trichodinids (Ciliata, Peritrichia) occurring on fish-pond carp for particular organs and some morphological implications. Acta Veterinaria (Beograd) vol. 53, no. 1, p. 41-46. http://dx.doi.org/10.2298/AVB0301041N

Santa Catarina, Brazil. Boletim do Instituto de Pesca, vol. 32, no. 1, p. $51-57$

STEIN, GA., 1968. Parasitic ciliates (Peritrichia, Urceolariidae) of fishes of the Amur basin. Acta Protozoologica, vol. 5, p. 229-244.

VAN AS, JG. and BASSON, L., 1989. A further contribution to the taxonomy of the Trichodinidae (Ciliophora: Peritrichia) and a review of the taxonomic status of some fish ectoparasitic trichodinids. Systematic Parasitology, vol. 14, p. 157-179. http:// dx.doi.org/10.1007/BF02187051

WELLBORN, TL., 1967. Trichodina (Ciliata: Urceolariidae) of freshwater fishes of the southern United States. Journal of Protozoology, vol. 14, p. 399-412. PMid:4963670.

YUKHIMENKO, SS., 1972. Parasites of young silver carp Hypophthalmichthys molitrix (Val.) and Ctenopharyngodon idella in the Amur River. Izvestiya Tikhookeanskogo NauchnoIssledovatel'skogo Instituta Rybnogo Khozyaistva Okeanografii, vol. 77, p. 151-159. 